\title{
So Near and Yet so Far: The Specific Case of Ralstonia solanacearum Populations from Côte d'Ivoire in Africa
}

\author{
C. A. N'Guessan, K. Abo, L. Fondio, F. Chiroleu, A. Lebeau, S. Poussier, E. Wicker, and D. Koné
}

First and eighth authors: University of Cocody-Abidjan, Abidjan, Côte d'Ivoire; first, fourth, fifth, and seventh authors: CIRAD, UMR 53 Peuplements Végétaux et Bioagresseurs en Milieu Tropical (PVBMT), Pole de Protection des Plantes, 7 chemin de l'IRAT, F-97410 Saint Pierre, Réunion, France; second author: Institut National Polytechnique Félix Houphouët Boigny (INPHB), Yamoussoukro, Côte d'Ivoire; third author: Centre National de Recherche Agronomique (CNRA), Anguédédou, Côte d'Ivoire; and sixth author: Université de La Réunion, UMR 53 Peuplements Végétaux et Bioagresseurs en Milieu Tropical (PVBMT), 15 avenue René Cassin, BP 7151, F-97715 Saint-Denis Cedex 9, Réunion, France.

Accepted for publication 17 April 2012.

\begin{abstract}
N'Guessan, C. A., Abo, K., Fondio, L., Chiroleu, F., Lebeau, A., Poussier, S., Wicker, E., and Koné, D. 2012. So near and yet so far: The specific case of Ralstonia solanacearum populations from Côte d'Ivoire in Africa. Phytopathology 102:733-740.

The genetic and phenotypic diversity of Côte d'Ivoire Ralstonia solanacearum strains was assessed on a 168-strain collection sampled on Solanaceae both in the southern lowlands and western highlands. Phylotypes I, II, and III were prevalent, though at unexpected frequencies. Phylotype I strains (87.5\%) were genetically diverse and overrepresented in all agroecological areas, including highlands (AEZ III). Phylotype II strains $(10.7 \%)$ only belonged to one tropical lowland-adapted broad host range lineage (IIA-35), whereas no highland-adapted potato brown rot (IIB-1) or Moko strains were detected. African phylotype III strains were rare $(1.8 \%)$. They originated from a single Burkina Faso lineage (III-23)

and were only found in lowlands. Three phylotype I strains were found harboring pRSC35, a plasmid identified in phylotype III strains in Cameroon. From pathogenicity tests performed on commercial varieties and tomato/eggplant/pepper references, the virulence diversity observed was high, with five pathoprofiles described. Eggplant accessions MM152 and EG203 and tomato HW7996 displayed the largest resistance spectrum and highest level. Two highly virulent phylotype I strains were able to bypass resistance of HW7996 and the eggplant reference AG9125. Collectively, these points lead to the conclusion that the situation in Côte d'Ivoire is specific towards other African countries, and specifically from the Cameroon reference, and that within phylotype I can exist a high virulence diversity. This calls for similar studies in neighboring West African countries, linking $R$. solanacearum pathogen genetic diversity to strain virulence at the regional level, for the rationalization of regional resistance deployment strategies and future resistance durability studies.
\end{abstract}

Ralstonia solanacearum E. F. Smith (47), the causal agent of bacterial wilt, is widespread in the tropics and subtropics and has emerged in temperate regions. This soilborne bacterium displays a broad host range of more than 450 species in 54 botanical families, including monocots and dicots (17). The disease has a severe impact on many economically important cash and subsistence crops, including potato, pepper, tomato, banana, peanuts, and tobacco $(2,8,19,22)$. Consequently, bacterial wilt caused by $R$. solanacearum is considered as one of the world's most destructive bacterial plant diseases. The pathogen is classified as a quarantine organism in Europe and listed among the bioterrorism select agents in the United States (26).

$R$. solanacearum enters into the plant through the roots (41) and colonizes the xylem vessels of its hosts. Disease symptoms in tomato plants include yellowing, stunting, and wilting. However, the pathogen can also develop latent infections in asymptomatic hosts thus maintaining high populations of bacterial cells (14).

Bacterial wilt management strategies include the use of resistant cultivars $(24,39)$, crop rotation, soil disinfection, and biological control (40). It is important to note that effective control depends on the subtle interaction between strains, the environ-

Corresponding author: E. Wicker; E-mail address: wicker@cirad.fr

E. Wicker and D. Koné contributed equally to this work.

* The $\boldsymbol{e}$-Xtra logo stands for "electronic extra" and indicates that the online version contains two supplemental figures and five supplemental tables.

http://dx.doi.org/10.1094/PHYTO-11-11-0300

(C) 2012 The American Phytopathological Society ment and soil characteristics. Strains of $R$. solanacearum are recognized to be highly diverse as shown by its unusually varied host range, geographical distribution, pathogenicity, and physiological properties (16)

Historically, the species complex was classified into races and biovars $(2,18)$, but these systems were neither predictive nor phylogenetically meaningful (27). In 2005, Fegan and Prior proposed a classification system divided into four phylotypes of different geographical origins, based on partial sequences of genes 16S rRNA, $h r p B$, and $e g l(10)$. Phylotypes are further subdivided into sequevars, based on the differences in the sequence of a portion of endoglucanase $(e g l)$ gene (45). Using this classification, strains are assigned to a specific phylotype and sequevar.

In Africa, bacterial wilt disease has been recognized as a major disease affecting vegetables. However, there is little available information on its actual prevalence and genetic diversity (8). The disease has been described for potato in 10 countries, including Kenya (34), and Ethiopia, where the incidence has increased from 45 to $63 \%$ (25). In southwestern Nigeria, a survey reported $80 \%$ of disease incidence in tomato fields in the Ogun State (1). In Mali, bacterial wilt caused by race 1 biovar 3 (phylotype I) strains was reported on potato, tomato, pepper, eggplant, tobacco and peanuts (37). However, the genetic and phenotypic diversity of African populations of $R$. solanacearum has yet to be described using a similar methodological approach to that applied in the extensive study by Mahbou Somo Toukam et al. (27) in Cameroon.

As in other African countries, bacterial wilt is a serious problem in Côte d'Ivoire, specifically for vegetables, which constitute 
a major part of local farm production throughout the country. Vegetable production is more intensive in specific areas in the South (Divo, Songon, Agnibilékro), the Center (areas of Yamoussoukro, Djebonoua, Toumodi), the West (Sinfra, Bakadense), and the North (Ferkéssédougou). Main crops include tomato, eggplant, bell pepper, pepper, cucumber, zucchini, and cantaloupe. There are few references on the situation of bacterial wilt due to $R$. solanacearum in Côte d'Ivoire. In 1984, the disease was observed on eggplant in an experimental plot at ORSTOM's Service Experimental Biologique in Adiopodoumé (South) with wilting incidence reaching 95\% in 1986 (6). In 2010, tomato bacterial wilt reached an incidence of $23.3 \%$ at the Centre National de Recherche Agronomique (CNRA) research station in Anguededou (7). According to disease resistance screenings performed on tomato and local eggplants, tomato cultivars from Israel and Taiwan were rated more resistant compared with the susceptible control 'Petomech'. Local eggplant cultivars called 'Ndrowa' and 'Klongbo' displayed a higher level of resistance than the cultivar 'Gbokouma' (12,35).

Implementing rational regional bacterial wilt control strategies will only be possible if questions of the genetic diversity, population structure, and virulence patterns of pathogen populations are addressed. The general trends that emerged from the extensive study of $R$. solanacearum populations in Cameroon (27), as well as in Ethiopia (25), showed that phylotypes I and IIA strains were mostly prevalent in the lowlands, whereas phylotypes III and IIB1 strains were preferentially established in the cooler highlands. As Côte d'Ivoire is composed of both lowland and highland areas, we set out to determine whether the bacterial wilt situation in Côte d'Ivoire was similar to that described in Cameroon. Considering both phylogenetic diversity and solanaceous accessions- virulence diversity as determined on an international resistant reference cultivar set (24), we specifically aimed to assess (i) whether the phylotype diversity in Côte d'Ivoire was similar to that in Cameroon; (ii) whether the distribution of phylotype I versus III in highlands and lowlands followed the "Cameroon model"; and (iii) which sources of plant resistance are most suitable for controlling Ivorian pathogen populations, as a starting point for the development of a regional breeding program for bacterial wilt resistance.

\section{MATERIALS AND METHODS}

Bacterial strains. Vegetable cropping areas were surveyed in 2010 (February, April, and September) and early 2011 (February) focusing on (i) the main cropping areas in Côte d'Ivoire (Fig. 1, Table 1) and (ii) putative bacterial wilt hot spots, i.e., locations (e.g., Bassam) where bacterial wilt outbreaks had already been reported by farmers. A total of 14 locations were sampled within four of the seven agroecological zones (AEZ) (15). The north (AEZ VI and VII) and center (AEZ V) could not be sampled during this period. Bacteria were isolated from stem bases of wilted eggplant, tomato, pepper, nightshade (Solanum scabrum), and "ortie-savane" (Croton hirtus, Euphorbiaceae). Plant samples were surface disinfected with $70 \%$ ethanol, chopped into small pieces and macerated in sterile distilled water. Macerates $(50 \mu \mathrm{l})$ were then streaked on solid Kelman's triphenyltetrazolium chloride (TZC) and modified Sequeira media (29). Plates were then incubated at $28^{\circ} \mathrm{C}$ for 2 or 3 days. Bacterial colonies that were morphologically typical of $R$. solanacearum were then selected and subcultured on fresh TZC medium for further purification. Each isolate was given a RUN accession number and

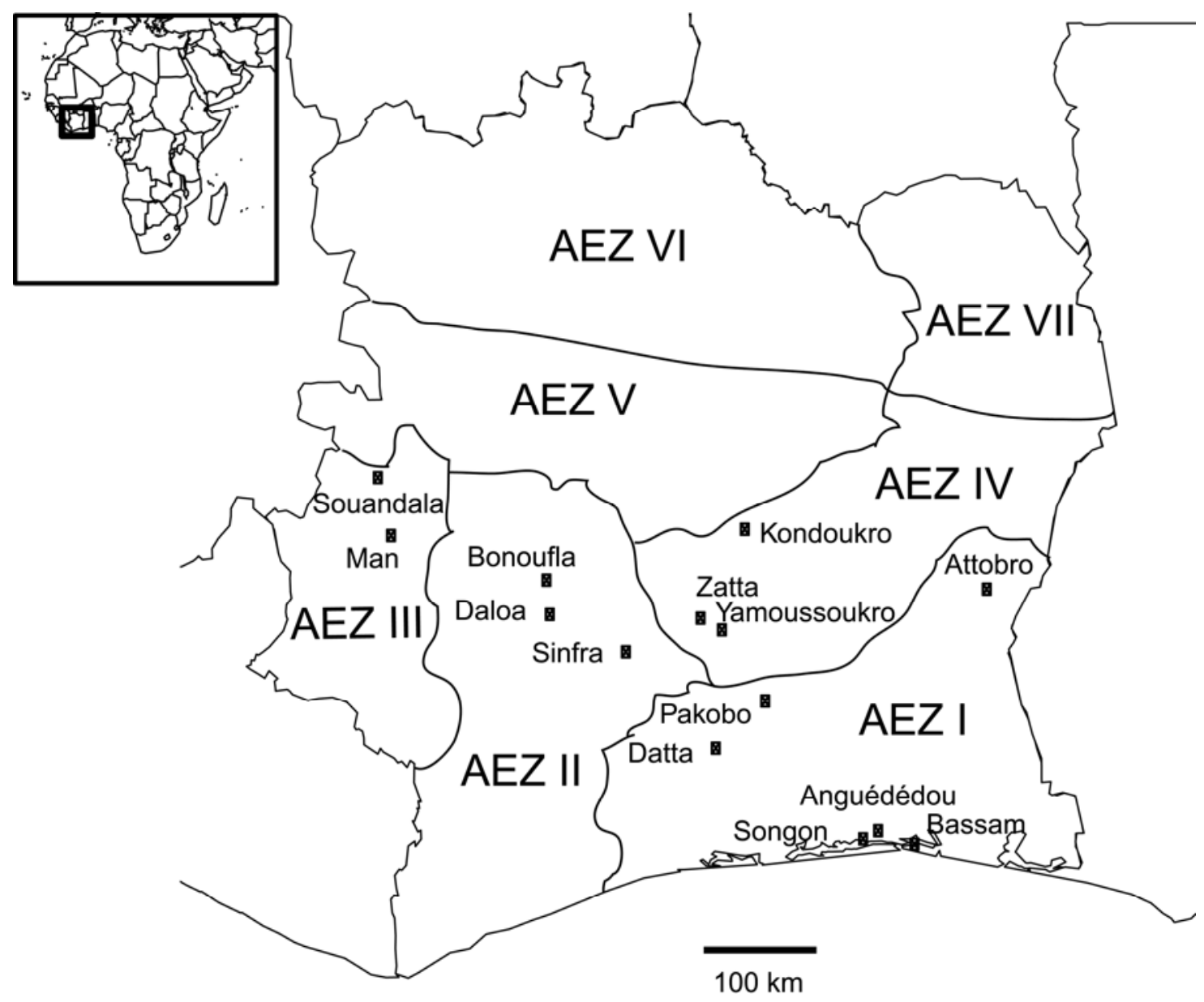

Fig. 1. Map of Côte d'Ivoire with the seven agroecological zones and the different localities surveyed. 
was then stored at $-80^{\circ} \mathrm{C}$ on Cryobank microbeads (COPAN Diagnostics, Marietta, CA92562).

Molecular typing. The phylotype was assigned to each strain after applying multiplex-polymerase chain reactions (PCRs) to bacterial suspensions $\left(\approx 10^{8}\right.$ cells $\left.\mathrm{ml}^{-1}\right)(10)$. Strains identified as phylotype II were further tested to determine whether they belonged to (i) the Moko ecotype that causes banana bacterial wilt (IIB-3, IIB-4, IIA-6, IIA-24, historically race 2 biovar 1) (11) by using the Musa multiplex PCR (Mmx-PCR), or (ii) potato brown rot (IIB-1, historically race 3 biovar 2) (9) ecotype by using 630/631 primer set, as previously described (27). All PCR products were resolved on a $2 \%$ agarose gel and visualized with UV light after ethidium bromide staining $\left(5 \mu \mathrm{g} \mathrm{ml}^{-1}\right)$.

DNA sequencing and analysis of endoglucanase $(e g l)$ and DNA repair (mutS) genes. The genetic diversity and phylogeny of strains were characterized using comparative analysis of the partial nucleotide sequences of egl and mutS genes. A 750-bp fragment of the $R$. solanacearum egl gene was amplified using the Endo-F/Endo-R primer pair. A 758-bp fragment of the mutS gene was amplified using the primers mutSRsF.1570 and mutSRsR.1926. PCRs were performed as previously described (45). PCR products were vacuum dehydrated and sent to Beckman Coulter Genomics (Takeley, UK) for further purification and double-strand sequencing using PCR primers as sequencing primers. Raw sequences from both strands were assembled using Pregap4.10 and Gap4.10 tools available from the Staden package (http://staden.sourceforge.net/), and fasta files were merged into multifasta files using Seqverter2.0.4.3 (http://www.genestudio. $\mathrm{com} /$ ). Sequences were edited with Gap4.10; all ambiguous sequences were reamplified and resequenced. Alignments were carried out using the ClustalW alignment tool (38) available in Mega 5.0 software (36), along with reference sequences $(32,46)$. Sequence extremities were trimmed on the basis of the sequence quality and reading frame; egl sequences were trimmed from the "start" codon up to the position 148 of IPO1609 (ACC GAC ACC). The mutS sequences were trimmed from the "start" codon up to the position 1897 of IPO1609 (GGC GGT AAA); positions 601 to 603 (GAT), apparently specific to some phylotype II strains, were eliminated, as well as positions 616 to 654 (13 codons), as already described (46). After assessment of the best fit nucleotide substitution model using jModelTest (28), phylogenetic trees were constructed for each gene using the Neighborjoining method (33) with 5,000 bootstrap resamplings. Assignment to $e g l$-based sequevars was conducted by using reference $e g l$ sequences (P. Prior and M. Fegan, 2008, unpublished data; 46). The mutS phylogenetic tree was rooted using partial sequences of $R$. insidiosa LMG21421, $R$. mannitolilytica LMG6866, and $R$. pickettii LMG5942 (46). From the pool of mutS and egl sequences included in this study, representative strain sequences were deposited into the GenBank database (Supplemental Table 1).

PCR-based detection of plasmid pRSC35 in Ivorian strains. The complete genome sequencing of strain CMR15, a highly virulent phylotype III strain isolated from Cameroon, made it possible to identify the $35-\mathrm{kb}$ plasmid pRSC 35 , containing several putative virulence genes and a type IV secretion system
(32). Given that this strain is unexpectedly more virulent on solanaceae than the other phylotype III strains $(4,24)$, this plasmid was putatively associated with increased virulence and aggressiveness. We investigated the presence of regions associated with this plasmid within Ivorian populations by using 10 primer pairs (Supplemental Table 2) targeting genes that are evenly distributed within the plasmid (Remenant and Cellier, personal communication 2010). PCR amplification of these genes was used as a diagnostic for the detection of pRSC35-associated regions. The reaction mixture $(25 \mu \mathrm{l})$ contained $1 \times$ PCR buffer, $1.5 \mathrm{mM}$ $\mathrm{MgCl}_{2}, 5 \%$ DMSO, $0.2 \mathrm{mM}$ of each dNTP (Ozyme, St. Quentin en Yvelines, France), $1 \mathrm{U}$ of RedGoldstar DNA Taq polymerase (Eurogentec, Angers, France), and $4 \mu \mathrm{M}$ of each primer (Genecust, Dudelenge, Luxemburg). PCRs consisted of an initial denaturation step at $96^{\circ} \mathrm{C}$ for $7 \mathrm{~min}$, followed by 30 cycles of $30 \mathrm{~s}$ at $95^{\circ} \mathrm{C}, 40 \mathrm{~s}$ at $58^{\circ} \mathrm{C}$, and $40 \mathrm{~s}$ at $72^{\circ} \mathrm{C}$ and a 10 -min final extension step at $72^{\circ} \mathrm{C}$. All were performed on Applied Biosystems GeneAmp PCR 9700 Thermocycler (Hayward, CA).

Pathogenicity tests. Nine representative strains (Table 2) chosen according to their phylotype and location of origin were assessed for virulence to solanaceae. Within this collection, two phylotype II strains from Sinfra and Datta were included, whereas

TABLE 2. Ralstonia solanacearum strains selected for the pathogenicity test, sorted by location and agroecological zone (AEZ)

\begin{tabular}{|c|c|c|c|}
\hline Strains & Location (AEZ) & Host of isolation & $\begin{array}{l}\text { Phylotype } \\
\text { sequevar }\end{array}$ \\
\hline RUN1538 & Songon (I) & Solanum lycopersicum & $\mathrm{I} / 14$ \\
\hline RUN1546 & Anguédédou (I) & Solanum melongena & $\mathrm{I} / 13$ \\
\hline RUN1761 & Datta (I) & Solanum lycopersicum & IIA/35 \\
\hline RUN1739 & Bonoufla (II) & Solanum lycopersicum & $\mathrm{I} / 18$ \\
\hline RUN1740 & Daloa (II) & Solanum melongena & $\mathrm{I} / 31$ \\
\hline RUN1747 & Sinfra (II) & Solanum lycopersicum & $\mathrm{I} / 46$ \\
\hline RUN1753 & Sinfra (II) & Solanum lycopersicum & IIA/35 \\
\hline RUN1744 & Man (III) & Solanum melongena & $\mathrm{I} / 31$ \\
\hline RUN1771 & Souandala (III) & Solanum lycopersicum & $\mathrm{I} / 18$ \\
\hline
\end{tabular}

TABLE 3. Solanaceous cultivars used in the pathogenicity tests

\begin{tabular}{llc}
\hline Species & \multicolumn{1}{c}{ Cultivars } & Seed source \\
\hline Solanum lycopersicum & Africa 82 ${ }^{\mathrm{a}}$ & \\
& PV & \\
& UC 82 & AVRDC \\
& T10 (L 390) & INRA \\
& T3 (NC 72 TR 4-4) & INRA \\
& T4 (Irat L3) & INRA \\
& T5 (Hawaii 7996) & INRA \\
& T8 (R3034) & \\
Solanum melongena & Black Beauty & INRA \\
& E1 (MM 853) & INRA \\
& E10 (Florida Market) & INRA \\
& E3 (MM152, Ceylan) & AVRDC \\
& E4 (EG203, Surya) & INRA \\
& E6 (MM960, AG91-25) & INRA \\
\hline
\end{tabular}

${ }^{a}$ Reference commercial cultivars cropped in Côte d'Ivoire.

TABLE 1. Characteristics of agroecological zones (AEZ) in Côte d'Ivoire ${ }^{\mathrm{a}}$

\begin{tabular}{|c|c|c|c|c|}
\hline AEZ & Characteristics & Elevation (m.a.s.1.) & Rainfall (mm) & Mean annual temperature (SD) \\
\hline I & South humid evergreen forest & 0-200 & $1,400-2,500$ (bimodal) & $29.0^{\circ} \mathrm{C}(5.6)$ \\
\hline II & West humid evergreen forest & $\approx 1,000$ (Daloa) & $1,300-1,750$ & $23.5^{\circ} \mathrm{C}(13.4)$ \\
\hline III & West highland forest & $>1,000$ (Man) & $1,300-2,300$ & $24.5^{\circ} \mathrm{C}(7.7)$ \\
\hline IV & Humid deciduous forest & $0-200$ & $1,300-1,750$ & $23.5^{\circ} \mathrm{C}(13.4)$ \\
\hline V & Transition forest zone & $300-600$ & $1,300-1,750$ (unimodal) & $23.5^{\circ} \mathrm{C}(13.4)$ \\
\hline VI & Humid tropical savannah zone & $300-500$ & $1,150-1,350$ (unimodal) & $26.7^{\circ} \mathrm{C}(1.1)$ \\
\hline VII & Dry tropical savannah zone & $300-500$ & $1,150-1,350$ & $26.7^{\circ} \mathrm{C}(1.1)$ \\
\hline
\end{tabular}

a The agroecological zones of Côte d'Ivoire were defined according to rainfall and temperature regimes and main agroecosystems (15).

b Meters above sea level. 
phylotype III strains were not tested. The plant accessions tested consisted of 15 cultivars of tomato, eggplant and pepper (Table 3 ) including: (i) a shortened version of CORE-TEP (24) named CORE-TEP 2 (23), that represented 11 internationally recognized reference genitors for resistance; and (ii) four tomato and eggplant varieties currently cropped throughout Côte d'Ivoire.

Bacterial suspensions were prepared in Tris buffer (Trizma $0.01 \mathrm{M}, \mathrm{pH} 7.1)$ and spectrophotometrically adjusted to optical density at $600 \mathrm{~nm}=0.1\left(\approx 1.0 \times 10^{8}\right.$ cells ml $\left.{ }^{-1}\right)$. Roots of plantlets with four fully extended leaves, grown in FLORADUR potting mix $(9 \times 9 \mathrm{~cm}$ pots $)$, were wounded with a scalpel and inoculated by soil drenching ( $5 \mathrm{ml}$ per plant). Each strain was inoculated on 10 plants from each accession. The plants were then kept in a growth chamber at $30^{\circ} \mathrm{C}$ day and $25^{\circ} \mathrm{C}$ night, $90 \%$ relative humidity and a $14 \mathrm{~h} / 10 \mathrm{~h}$ photoperiod. The experiment was repeated once.

Bacterial wilt incidence and severity were monitored every 2 or 3 days for 28 days by using a 0 to 4 scale: $0=$ no symptoms, $1=$ one wilted leaf, $2=$ two or three wilted leaves, $3=$ all leaves wilted, and $4=$ stem collapsed and plant dead (5). Each plant that scored 3 or 4 was considered wilted.

Plants showing no symptoms at the end of the experiment were harvested and tested for latent infections as previously reported (24). The percentage of wilted plants and the colonization index (30) were accessed.

Data analysis. Some working concepts were used in this study. $R$. solanacearum-solanaceae interactions were previously summarized by six groups named pathoprofiles (24), based on the combination of final wilting incidence and colonization index (CI) scores. A pathoprofile is defined as a group of strains that present similarities in their pattern of virulence on a collection of solanaceous accessions (24). Consequently, pathoprofiles were defined on the basis of a phenotype score, which combines wilting incidence and colonization index (30). Phenotypic groups were defined as a group of strains that presented similarities in their virulence on the 15 accessions in this study.

Previous cluster analysis of the CoreTEP-coreRs2 interactions (considering both wilting incidence and CI scores) led to the identification of five phenotypic plant groups, named reference phenotypes, ranging from 1 to 5 : $1=$ highly resistant, $2=$ moderately resistant, 3.1 = partially resistant, $3.2=$ latent infection, $4=$ moderately susceptible, and $5=$ highly susceptible (24). On the basis of the respective final wilting rate and colonization index, each combination strain-cultivar was assigned to a reference phenotype score, by using the " $k$ nearest neighbor" algorithm (knn) in the package class of R software version 2.10.1 (42).

The strains were clustered on the basis of each phenotype score for all the accessions tested, using an ascending hierarchical classification system (agnes function within the package "cluster") with the Euclidean distance and considering the "Ward" method (21). The number of phenotypic groups was determined using the internode distance of the dendrogram and phenotypic scores.

Moreover, the pathoprofile of each strain (24) was determined using the $k$ nearest neighbor algorithm on the phenotype scores obtained on the reference cultivars only (11 accessions). The effect of strain and plant accession on wilting incidence and on the area under the disease progression curve (AUDPC) was assessed using a generalized linear model and an analysis of

TABLE 4. Phylotype distribution of Ivorian strains within agroecological zones

\begin{tabular}{lcclc}
\hline AEZ & Phylotype I & Phylotype IIA & Phylotype III & Total \\
\hline I & $74(87.1 \%)^{\mathrm{a}}$ & $11(13.0 \%)$ & - & 85 \\
II & $33(82.5 \%)$ & $7(17.5 \%)$ & - & 40 \\
III & $19(100 \%)$ & - & - & 19 \\
IV & $21(87.5 \%)$ & - & $3(12.5 \%)$ & 24 \\
Total & $147(87.5 \%)$ & $18(10.7 \%)$ & $3(1.8 \%)$ & 168 \\
\hline
\end{tabular}

a Percentage of the different phylotypes within each agroecological zone (AEZ). variance, respectively. Incidence and AUDPC means were compared within each group and pathoprofile and between groups and pathoprofiles, using a pairwise comparison test based on Tukey's method at level 0.05 (package $\mathrm{glm}$, R software).

\section{RESULTS}

Molecular characterization of $\boldsymbol{R}$. solanacearum strains and phylogenetic analysis. A total of 168 strains were collected. Most strains were isolated from wilted tomato and sampled in 14 localities at AEZ I, II, III, and IV (south humid evergreen forest, west humid evergreen forest, west highland forest, and humid deciduous forest). Localities in the north (AEZ V, VI, and VII), particularly the vegetable cropping areas in Korhogo and Odienné, were not surveyed.

The phylogenetic trees based on egl and mutS sequences gave similar clusters. Structures of the different groups based on the analysis of both genes were consistent. However, sequevars were determined using egl sequences only.

Three out of the four known phylotypes of $R$. solanacearum were identified in Côte d'Ivoire: the Asian phylotype I, the American phylotype II, and the African phylotype III. The collection predominantly constituted strains of phylotype I $(87.5 \%)$ (Table 4), which were isolated from all 14 localities. Phylogenetic

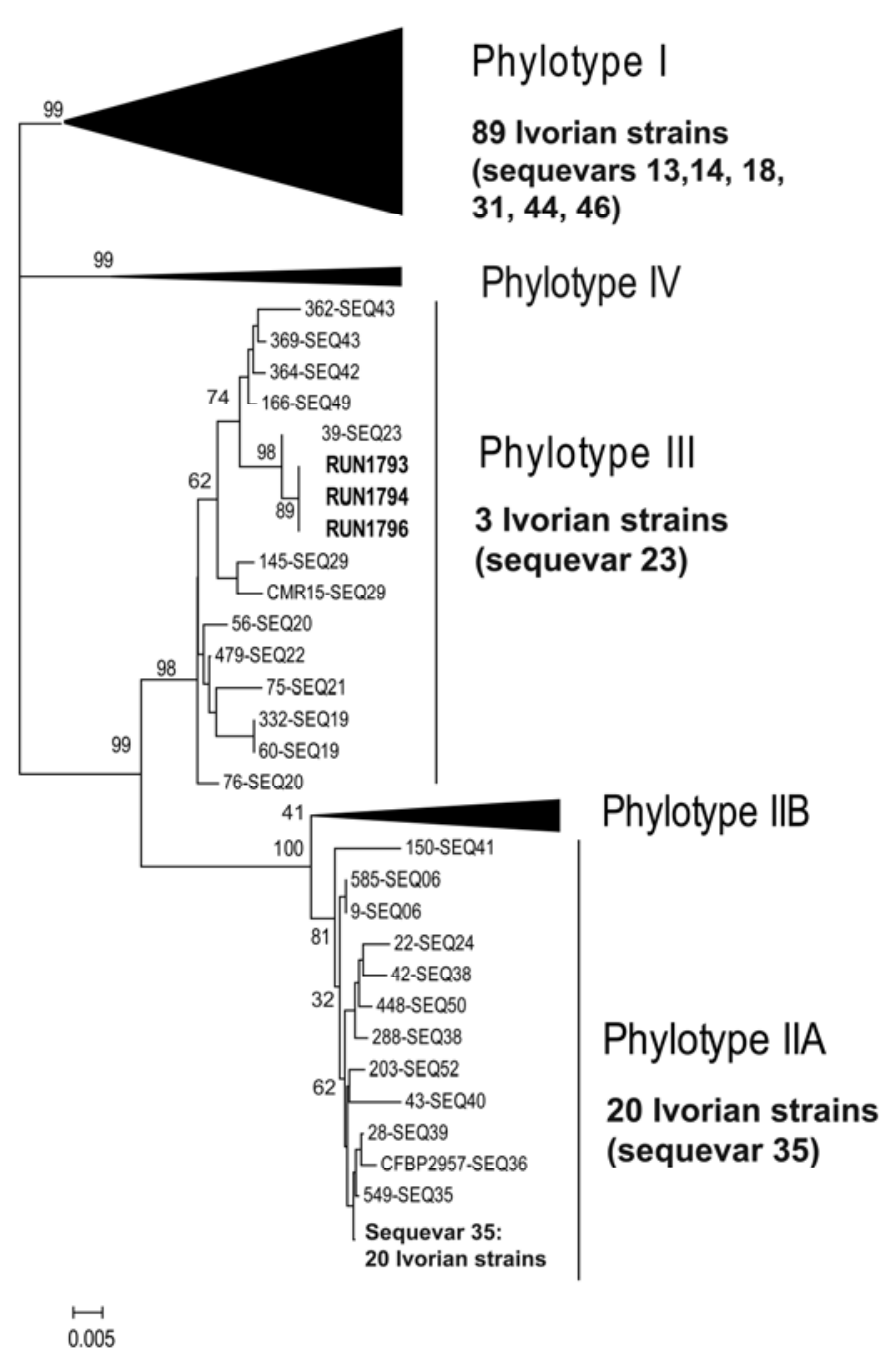

Fig. 2. Neighbor-joining phylogenetic tree based on the partial endoglucanase (egl) gene sequences of Ralstonia solanacearum strains from Côte d'Ivoire and reference strains. Numbers at each node are bootstrap values (5,000 resamplings). Reference strains are identified by their RUN number and sequevar (SEQ) number. 
analysis showed that phylotype I strains were distributed within six egl-based sequevars: I-13, I-14, I-18, I-31, I-44, and I-46 (Fig. 2), and two mutS-based sequence types (ST) (Fig. 3). The most widespread sequevar I-31 was prevalent in six localities and four AEZ (Sinfra and Daloa [AEZ II], Man [AEZ III], Attobro [AEZ I], Zatta and Yamoussoukro [AEZ IV]). Conversely, the sequevar
I-44 was only represented in the Souandala (AEZ III) area, where it was isolated from eggplant. The most diverse locality was Sinfra, which had four sequevars (I-18, I-14, I-31, and I-46).

Strains of phylotype II, representing $10.7 \%$ of the collection, were all isolated from tomato in three localities and two AEZ:

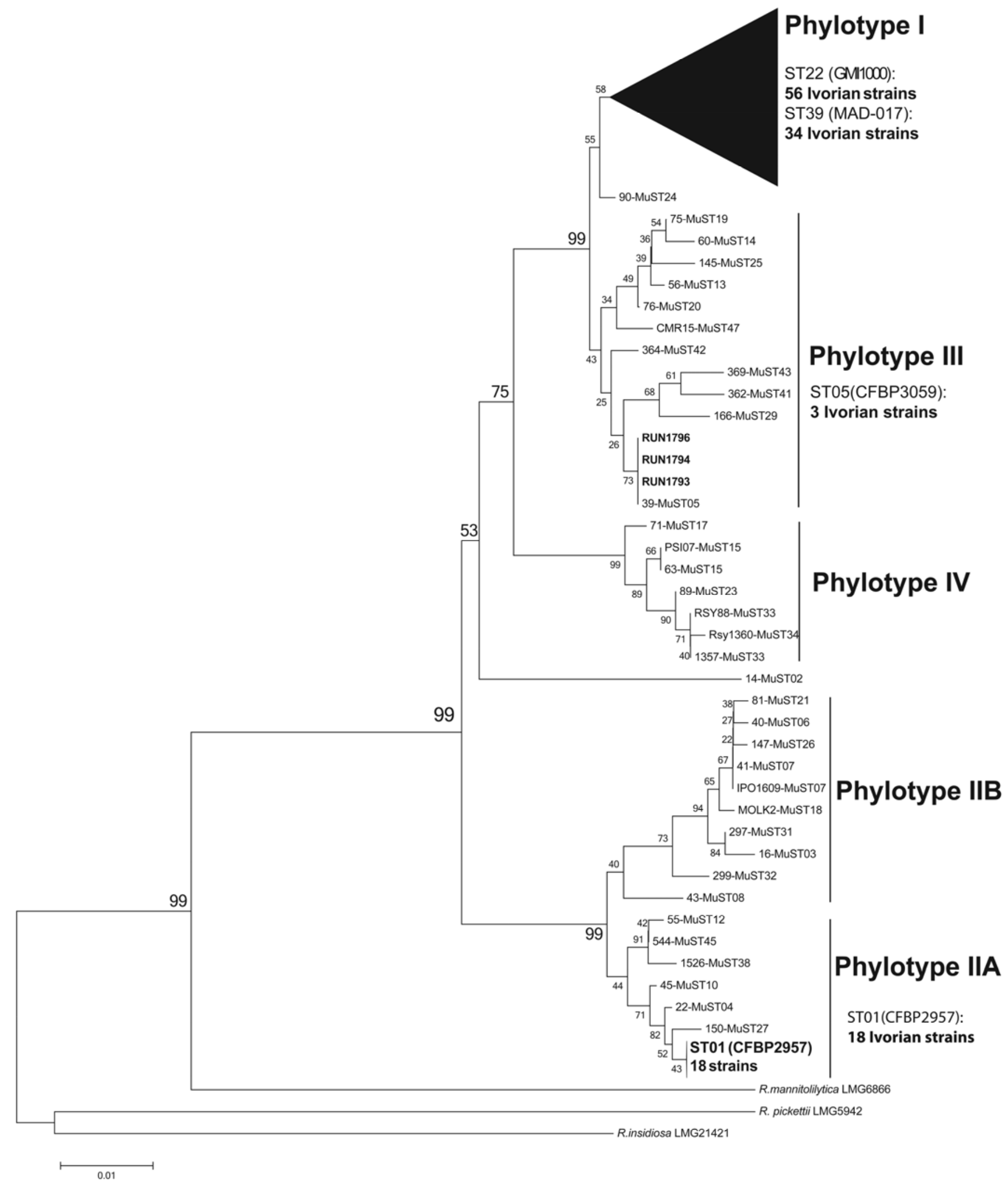

Fig. 3. Neighbor-joining phylogenetic tree based on DNA repair gene (mutS) sequences of Ralstonia solanacearum strains from Côte d'Ivoire and reference strains. Numbers at each node are bootstrap values (5,000 resamplings). Strains are identified by their RUN number and their $m u t S$ sequence type (muST) number. 
Datta and Pakobo (AEZ I) and Sinfra (AEZ II). All were phylotype IIA sequevar 35 (IIA-35). Potato "brown rot" (IIB-1 formerly race 3 biovar 2) and the Moko disease-causing strain were not identified.

Only three phylotype III strains (1.8\% of the collection) were sampled from eggplant in a single locality (Kondoukro, AEZ IV). These strains were assigned to phylotype III sequevar 23 along with the reference strain from Burkina Faso (CFBP3059).

Presence of pRSC35 in strains in Côte d'Ivoire. Nine genes carried by pRSC35 were successfully amplified within three strains from the same location (Supplemental Figure 1), whereas the cytosine methyltransferase gene (primers plsd01-F/R) was not amplified. Plasmid gene-hosting strains (RUN1752, RUN1756 and RUN1758) were all in phylotype I and isolated from tomato in the Sinfra locality (AEZ II).

Phenotypic interactions between plant accessions and strains. The wilting incidence, colonization index and AUDPC were not significantly different across the two replicates $(P=$ $0.171,0.201$, and 0.404 , respectively). Therefore, the subsequent analyses were based on the mean results. According to pathogenicity data (Fig. 4, Supplemental Table 3), the four Ivorian varieties (Africa, UC82, PV, and Black Beauty) scored highly susceptible to all strains tested, although Black Beauty was only slightly affected by the phylotype IIA-35 strain RUN 1761. This strain also failed to wilt the susceptible control plant E10 and T10. Resistance levels and spectra varied among Core-TEP 2 accessions. Most of the tomato lines were classed as susceptible in our experimental conditions. The most resistant cultivar was Hawaii 7996, which controlled most of the strains tested (24). However, it was classed as susceptible to three phylotype I strains originating from Bonoufla (RUN 1739), Daloa (RUN1740) and Man (RUN 1744). The highest resistance levels and broadest resistance spectra were displayed by the eggplant accessions E4, E3, and E1. However, E3 was classed as partially resistant to strain RUN 1740 and E1 was susceptible to strain RUN 1744. Complete incompatible interactions (no wilt and no bacterial colonization) were observed on the couples: (i) E3 $\times$ RUN 1739 (phylotype I, Bonoufla [AEZ II]) and E3 $\times$ RUN 1753 (phylotype IIA-35, Sinfra [AEZ II]), (ii) E4 × RUN 1753 (phylotype IIA-35, Sinfra), and (iii) E1 $\times$ RUN 1538 (phylotype I, Songon [AEZ I]) and E1 $\times$ RUN 1761 (phylotype IIA-35, Datta [AEZ I]).
Phenotypic groups and pathoprofiles. Considering all the cultivars tested, the method based on internode distance and phenotype score indicated that clustering into three phenotypic groups was the most reliable system of partition (Fig. 4). Group 1 encompassed phylotype IIA strains RUN 1753 and RUN 1761, was characterized as weakly virulent and aggressive, affecting only the susceptible cultivars; group 2 encompassed five of the nine strains tested and was characterized by a low virulence on E6 and T5 cultivars (although RUN 1739 was virulent to T5); and group 3 contained the strains RUN 1740 and RUN 1744 (both in phylotype I-31), and was characterized by a broad virulence spectrum and a high aggressiveness level on all accessions except E3 and E4.

When only the accessions placed in Core-TEP 2 are considered, the Ivorian strains were assigned within five of the six reported pathoprofiles (24). Strains RUN 1538, RUN 1546, and RUN 1771 clustered within pathoprofile a; RUN 1739 within pathoprofile b; RUN 1753, RUN 1761, and RUN 1747 in pathoprofile c; RUN 1740 in pathoprofile e; and RUN 1744 in pathoprofile $\mathrm{f}$. There was a very highly significant difference between strains, phenotypic groups and profiles $\left(P<10^{-4}\right)$. Strains were similarly virulent to the Ivorian cultivars $(P=0.1737)$, but highly significant differences in virulence were observed $(P<$ $10^{-4}$ ) when considering the Core TEP 2 accessions (Supplemental Tables 4 and 5).

\section{DISCUSSION}

This phylogenetic study shows that the populations of $R$. solanacearum prevalent in Côte d'Ivoire have considerable genetic diversity and that their composition and distribution is highly specific when compared to other African situations, particularly Cameroon. Ivorian strains were distributed in three of the four phylotypes described: I, II, and III, as expected from previous reports in Africa $(8,27)$. However, the distribution of the different phylotypes was clearly specific to this country. Phylotype I strains were the major group $(87.5 \%$ of the collection), and were widespread in the four agroecological zones surveyed, including the highland AEZ III. Whereas in Cameroon, phylotype I strains represent $45.5 \%$ of the collection (27). Phylotype II strains were relatively rare $(10.7 \%$ of the collection)

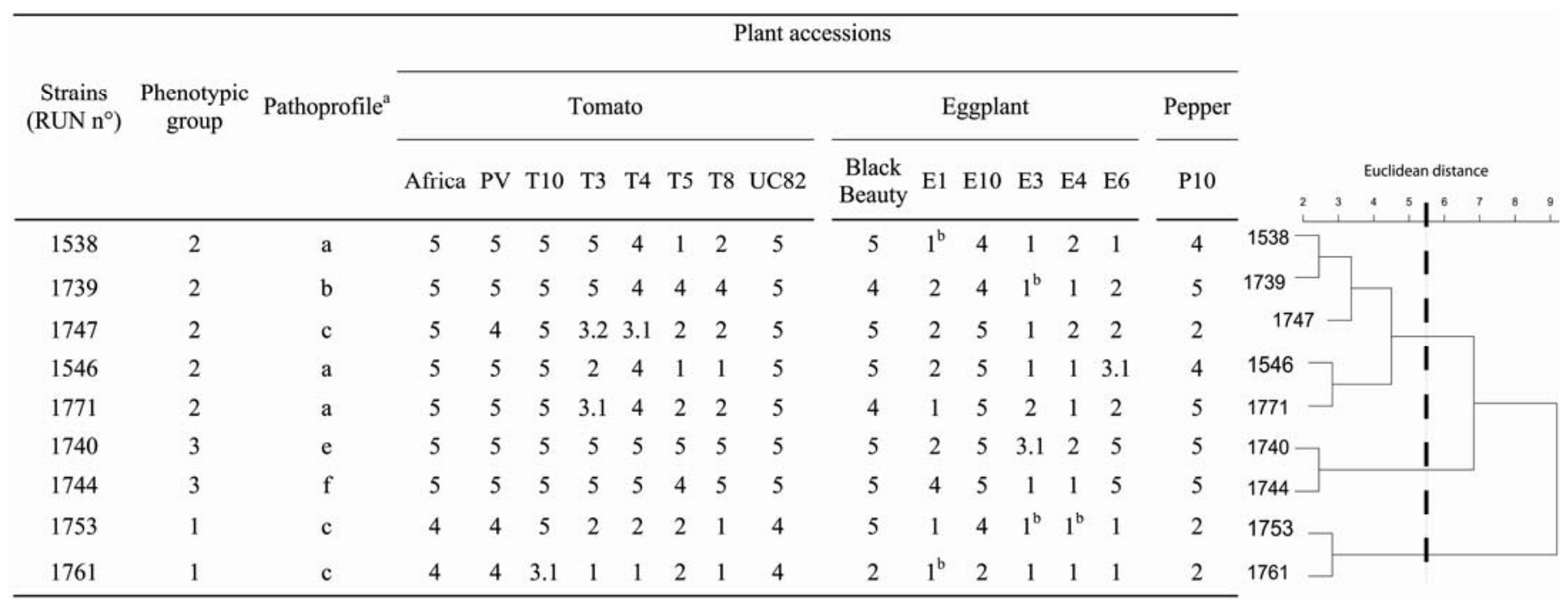

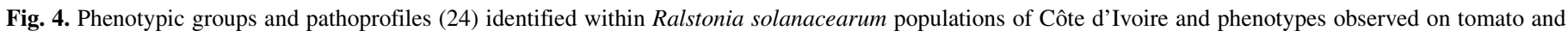

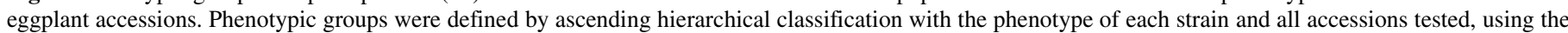

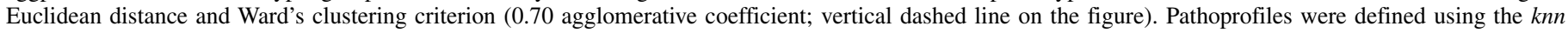

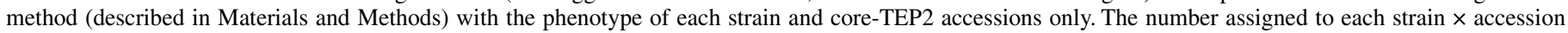

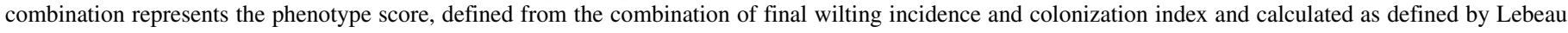

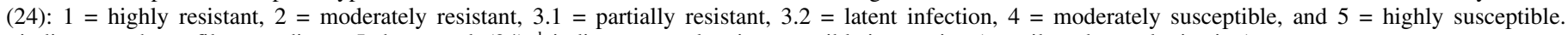
$\mathrm{a}$ indicates pathoprofile according to Lebeau et al. (24), ${ }^{\mathrm{b}}$ indicates complete incompatible interaction (no wilt and no colonization). 
compared with Cameroon (36.3\%). They were clustered in three locations in the lowland AEZ I and II only and showed little diversity (one unique egl-based sequevar, one unique mutS sequence type). Potato brown rot strains (phylotype IIB-sequevar 1 , formerly race $3 /$ biovar 2 ) were not reported, even in the elevated AEZ II and III, unlike in Cameroon where race 3 biovar 2 was identified in the highlands. This point could be explained by the fact that potato is not yet cropped in family farming systems, contrary to practices in neighboring countries (Mali, Guinea, Burkina Faso, Niger) and in Central Africa (Cameroon). Besides, no Moko disease-causing strains (IIA-6 and IIA-24, IIB3 and IIB-4) or "emerging" strains (IIB-4NPB), were reported, even in areas where tomato is often rotated with cooking banana, such as Sinfra (AEZ II). Phylotype IIB-4NPB strains were shown to have emerged in areas of traditional banana-vegetable rotations in Martinique $(44,45)$. However, the results of this study may suggest that this emergence is specific to American $R$. solanacearum populations.

The other unexpected result was the distribution of the African phylotype III in Côte d'Ivoire. This clade was the least prevalent $(1.8 \%)$. No strains were isolated in the highland AEZ III, whereas only three strains collected from eggplant were isolated in the lowland region of Kondoukro (AEZ IV). We suspect that these strains were introduced from abroad because Kondoukro is located in a very active "economic hub" where plant products are transited from several neighboring countries (Burkina Faso, Guinea, Mali, Niger), and because the strains were found to be phylogenetically close to a Burkina lineage (egl-based sequevar 23, mutS ST05). Additional surveys will investigate the possible phylotype III prevalence in Northern Côte d'Ivoire. This study is one of the rare reports of phylotype III prevalence in lowland cropping areas because phylotype III was thought to establish preferentially in the highlands in Cameroon (27) and in Réunion and Madagascar (E. Wicker and P. Prior, unpublished data). Collectively, these points lead to the conclusion that the situation in Côte d'Ivoire does not follow the Cameroon model.

The plasmid pRSC35 or more specifically pRSC35-associated genes were only found in three out of 168 phylotype I strains, indicating a low prevalence $(1.8 \%)$. The detection of plasmidassociated regions in phylotype I strains is a novelty. Until now, they were only found in two phylotype III strains (CMR15 and CMR20) (32). The occurrence of small plasmids with low copies in $R$. solanacearum cells has already been reported. However, further in-depth investigation is required to determine their biological role, as well as their actual distribution in natural populations $(13,32)$.

Although the pathoprofile of phylotype III has not been determined (pathogenicity tests are currently in progress), the picture that emerges is one of a pathogen population in the Côte d'Ivoire that is phylogenetically homogenous (phylotype I mostly) but with high virulence diversity (five pathoprofiles). From this study, Ivorian populations displayed a higher virulence diversity (five pathoprofiles out of six: a, b, c, e, and f) than that observed in Cameroon: Cameroon strains tested on the international set CORE-TEP (24) ranked in pathoprofiles a (CMR134, I;), c (CMR 32, III-29; CMR39, IIA-41), and e (CMR15, III-29; CMR34, IIB1). However, we cannot exclude the fact that some highly virulent strains exist in Cameroon, which were not tested. From the different analyses (phenotypic groups, pathoprofiles), the Ivorian phylotype IIA strains (RUN1753, RUN1761) appeared less virulent, as already observed on Cameroon strains (24). However, two strains were assigned to highly virulent profiles e (RUN1740) and $f$ (RUN1744). RUN1740 virulence was thus similar to that of two strains from Cameroon (CMR15 and CMR34) and to the Taiwanese phylotype I strain PSS4, which overcomes the major dominant resistance gene carried by E6. RUN 1744 virulence appeared similar to that of CFBP6783, a pathogenic variant (IIB4NPB) first described in Martinique (45), bypassing all known tomato resistance sources (43) and resistant eggplants except E2 (MM643), E3, and E4 (24). Given that IIB-4NPB strains were reported to be highly virulent on cucurbitaceous, Solanaceae, Heliconiaceae, and Anthurium species, further investigation of the pathogenicity of RUN 1744 to these hosts may be useful. As far as we know, the most virulent and aggressive phylotype I strains (ex-biovar 3, 4, and 5) have only been reported in Asia, specifically in Taiwan $(20,39)$. However, phylotype I strains have been reported to be less virulent than the other phylotypes in the Indian Ocean (3), America and the Caribbean $(31,43,45)$. This is the first report of the isolation of highly virulent phylotype I strains outside of Asia. The extent of the distribution of the Ivorian pathoprofile $\mathrm{f}$ strains in Côte d'Ivoire, as well as throughout Western Africa has yet to be determined.

This phylogenetic study can be considered a starting point for the development of any vegetable screening or breeding program for bacterial wilt resistance in Côte d'Ivoire. The commercial tomato and eggplant varieties cropped in Côte d'Ivoire were highly susceptible in our controlled inoculation conditions. This illustrates the importance of adequate resistance genitors. We identified resistance genitors suitable for Côte d'Ivoire and can propose some guidelines for their regional deployment. Regarding tomato, T5 (HW7996), and to a lesser extent T8 (R3034) are the best genitors available. However, their resistance was overcome by strains of Bonoufla and Daloa (AEZII), and Man (AEZ III). As far as the eggplant is concerned, the Asian eggplant E3 (MM152 syn 'Ceylan') and E4 (EG203 syn 'Surya') are the most promising because they are resistant to all strains tested, although E3 was only tolerant to the Daloa strain (AEZII). Whereas, the reference E6 (AG91-25), carrying the dominant resistance gene Ers1 (22), was overcome by the Daloa strain (AEZ II) and the Man strain (AEZ III). The reference E1 (Dingras), thought to provide the broadest resistance spectrum (24), was also bypassed by the Man strain. From these findings, cropping solanaceae in the Daloa and Man regions may be considered more risky and will require the implementation of additional control measures (suppressive crops, rotations, etc.) to control bacterial wilt. These findings are a real incentive to encourage plant breeders to use these eggplant accessions and the tomato line Hawaii 7996 as genetic resources for creating regionally adapted cultivars for the benefit of the Ivorian population.

In summary, our study provides the first picture linking $R$. solanacearum pathogen genetic diversity to strain virulence in Côte d'Ivoire. This constitutes a major step for the rationalization of regional resistance deployment strategies and calls for similar studies in neighboring West African countries. More specifically, it means that the distribution of the resistance specificity of the eggplant reference genitor AG91-25 can be determined.

We also show that Côte d'Ivoire appears free of the brown rot phylotype IIB-1 strain. This highly virulent lineage of $R$. solanacearum should be carefully quarantined for any importations of potato seed tubers.

\section{ACKNOWLEDGMENTS}

We thank S. Lebon, J.-M. Baptiste, J.-J. Cheron, and C. Boyer for their excellent technical assistance and O. Pruvost for his critical review of the manuscript. This work was financially supported by the Agence Universitaire de la Francophonie (AUF), and CIRAD-DESI. The European Regional Development Funds (FEDER) of the European Union and the Conseil Régional de la Réunion also provided funds as part of the program "Lutte génétique contre les maladies émergentes chez les solanées maraîchères" (GENETOM).

\section{LITERATURE CITED}

1. Adebayo, O. S., and Ekpo, E. J. A. 2005. Biovar of Ralstonia solanacearum causing bacterial wilt of tomato in Nigeria. Plant Dis. 89:1129.

2. Buddenhagen, I., and Kelman, A. 1964. Biological and physiological 
aspects of bacterial wilt caused by Pseudomonas solanacearum. Annu. Rev. Phytopathol. 2:203-230.

3. Carmeille, A., Caranta, C., Dintinger, J., Prior, P., Luisetti, J., and Besse, P. 2006. Identification of QTLs for Ralstonia solanacearum race 3phylotype II resistance in tomato. Theor. Appl. Gen. 113:110-121.

4. Cellier, G., and Prior, P. 2010. Deciphering phenotypic diversity of Ralstonia solanacearum strains pathogenic to potato. Phytopathology 100:1250-1261.

5. Coupat-Goutaland, B., Bernillon, D., Guidot, A., Prior, P., Nesme, X., and Bertolla, F. 2011. Ralstonia solanacearum virulence increased following large interstrain gene transfers by natural transformation. Mol. PlantMicrobe Interact. 24:497-505.

6. Declert, C. 1987. Bilan sanitaire des plantes maraichères Campagne 8687. Fond documentaire ORSTOM.

7. Djidji, A. H., Zohouri, G. H., Fondio, L., N'zi, J. C., and Kouamé, N. C. 2010. Effet de l'abri sur le comportement de la tomate (Solanum lycopersicum L.) en saison pluvieuse dans le sud de la Côte-d'Ivoire. J. Appl. Biosci. 25:1557-1564.

8. Elphinstone, J. G. 2005. The current bacterial wilt situation: A global overview. Pages 9-28 in: Bacterial Wilt Disease and the Ralstonia solanacearum Species Complex. C. Allen, P. Prior, and A. C. Hayward, eds. The American Phytopathological Society, St. Paul, MN.

9. Fegan, M., Holloway, G., Hayward, A. C., and Timmis, J. 1998. Development of a diagnostic test based on the polymerase chain reaction (PCR) to identify strains of R.solanacearum exhibiting the biovar 2 genotype. Pages 34-43 in: Bacterial Wilt Disease-Molecular and Ecological Aspects. P. Prior, C. Allen, and J. Elphinstone, eds. SpringerVerlag, INRA Editions, Berlin, Paris.

10. Fegan, M., and Prior, P. 2005. How complex is the "Ralstonia solanacearum species complex". Pages 449-462 in: Bacterial Wilt Disease and the Ralstonia solanacearum Species Complex. C. Allen, P. Prior, and A. C. Hayward, eds. The American Phytopathological Society, St. Paul, MN.

11. Fegan, M., and Prior, P. 2006. Diverse members of the Ralstonia solanacearum species complex cause bacterial wilts of bananas. Austral. Plant Pathol. 35:93-101.

12. Fondio, L., N'Tamon, L., Hala, F. N., and Dijdji, H. 2008. Agronomic evaluation of six cultivars of African eggplant (Solanum spp.) of the new vegetable collection of CNRA. Agron. Africaine 20:69-79.

13. Genin, S., and Boucher, C. 2004. Lessons learned from the genome analysis of Ralstonia solanacearum. Annu. Rev. Phytopathol. 42:107-134.

14. Grimault, V., and Prior, P. 1993. Bacterial wilt resistance in tomato associated with tolerance of vascular tissues to Pseudomonas solanacearum. Plant Pathol. 42:589-594.

15. Halle, B., and Bruzon, V. 2006. Profil environnemental de la Côte d'Ivoire. Pages 133. in: Contrat Cadre EuropeAid/119860/C/SV/Multi A. Consult, ed. Commission Européenne, Bruxelles, Belgium.

16. Hayward, A. C. 1991. Biology and epidemiology of bacterial wilt caused by Pseudomonas solanacearum. Annu. Rev. Phytopathol. 29:65-87.

17. Hayward, A. C. 1994. The hosts of Pseudomonas solanacearum. Pages 924 in: Bacterial Wilt-The Disease and Its Causative Agent, Pseudomonas solanacearum. A. C. H. Hayward and G. L. Hartman, eds. CAB International, Wallingford, UK.

18. Hayward, A. C., and Hartman, G. L. 1994. Bacterial Wilt: The Disease and Its Causative Agent, Pseudomonas solanacearum. CAB International, Wallingford, UK.

19. Janse, J. D. 1996. Potato brown rot in Western Europe-history, present occurrence and some remarks on possible origin, epidemiology and control strategies. Bull. OEPP/EPPO Bull. 26:679-695.

20. Jaunet, T. X., and Wang, J. F. 1999. Variation in genotype and aggressiveness of Ralstonia solanacearum race 1 isolated from tomato in Taiwan. Phytopathology 89:320-327.

21. Kaufman, L., and Rousseuw, P. J. 2005. Finding Groups in Data : An Introduction to Cluster Analysis. John Wiley \& Sons, Hoboken, NJ.

22. Kelman, A. 1953. The bacterial wilt caused by Pseudomonas solanacearum. North Carolina Agric. Exp. Stn. Tech. Bull. 99:1-194.

23. Lebeau, A. 2010. Résistance de la tomate, l'aubergine et le piment à Ralstonia solanacearum: Interactions entre les géniteurs de résistance et la diversité bactérienne, caractérisation et cartographie des facteurs génétiques impliqués chez l'aubergine. Ph.D. Faculté des Sciences et Technologies, Université de la Réunion, Saint Denis de la Réunion.

24. Lebeau, A., Daunay, M. C., Frary, A., Palloix, A., Wang, J. F., Dintinger, J., Chiroleu, F., Wicker, E., and Prior, P. 2011. Bacterial wilt resistance in tomato, pepper, and eggplant: Genetic resources respond to diverse strains in the Ralstonia solanacearum species complex. Phytopathology 101:154-165.

25. Lemessa, F., and Zeller, W. 2007. Isolation and characterisation of Ralstonia solanacearum strains from Solanaceae crops in Ethiopia. J.
Basic Microbiol. 47:40-49.

26. Madden, L. V., and Wheelis, M. 2003. The threat of plant pathogens as weapons against U.S. crops. Annu. Rev. Phytopathol. 41:155-176.

27. Mahbou Somo Toukam, G., Cellier, G., Wicker, E., Guilbaud, C., Kahane, R., Allen, C., and Prior, P. 2009. Broad diversity of Ralstonia solanacearum strains in Cameroon. Plant Dis. 93:1123-1130.

28. Posada, D. 2008. jModelTest: Phylogenetic Model Averaging. Mol. Biol. Evol. 25:1253-1256

29. Poussier, S., Cheron, J. J., Couteau, A., and Luisetti, J. 2002. Evaluation of procedures for reliable PCR detection of Ralstonia solanacearum in common natural substrates. J. Microbiol. Methods 51:349-359.

30. Prior, P., Bart, S., Leclercq, S., Darrasse, A., and Anaïs, G. 1996. Resistance to bacterial wilt in tomato as discerned by spread of Pseudomonas (Burkholderia) solanacearum in the stem tissues. Plant Pathol. 45:720-726.

31. Ramsubhag, A., Lawrence, D., Fraser, R., Umaharan, P., Prior, P., and Wicker, E. 2012. Wide genetic diversity of Ralstonia solanacearum strains affecting tomato in Trinidad, West Indies. Plant Pathol. Early View doi:10.1111/j.1365-3059.2011.02572.x.

32. Remenant, B., Coupat-Goutaland, B., Guidot, A., Cellier, G., Wicker, E., Allen, C., Fegan, M., Pruvost, O., Elbaz, M., Calteau, A., Salvignol, G., Mornico, D., Mangenot, S., Barbe, V., Medigue, C., and Prior, P. 2010. Genomes of three tomato pathogens within the Ralstonia solanacearum species complex reveal significant evolutionary divergence. BMC Gen. 11(379):1-16.

33. Saitou, N., and Nei, M. 1987. The neighbor-joining method: A new method for reconstructing phylogenetic trees. Mol. Biol. Evol. 4:406-425.

34. Smith, J. J., Offord, L. C., Holderness, M., and Saddler, G. S. 1995. Genetic diversity of Burkholderia solanacearum (synonym Pseudomonas solanacearum) race 3 in Kenya. Appl. Environ. Microbiol. 61(12):42634268.

35. Soro, S., Doumbia, M., Dao, D., Andres, T., and Girardin, O. 2007. Performances de six cultivars de tomate Lycopersicon esculentum Mills contre la jaunisse en cuillère des feuilles, le fletrissement bactérien et les nematodes à galles. Sci. Nature 4:123-130.

36. Tamura, K., Peterson, D., Peterson, N., Stecher, G., Nei, M., and Kumar, S. 2011. MEGA5: Molecular evolutionary genetics analysis using maximum likelihood, evolutionary distance, and maximum parsimony methods. Mol. Biol. Evol. 28(10):2731-2739.

37. Thera, A. T., Jacobsen, B. J., and Neher, O. T. 2010. Bacterial wilt of solanaceae caused by Ralstonia solanacearum race 1 biovar 3 in Mali. Plant Dis. 94:372-372.

38. Thompson, J. D., Higgins, D. G., and Gibson, T. J. 1994. CLUSTAL W: Improving the sensitivity of progressive multiple sequence alignment through sequence weighting, position-specific gap penalties and weight matrix choice. Nucleic Acids Res. 22:4673-4680.

39. Truong, T. H. H., Esch, E., and Wang, J. 2008. Resistance to Taiwanese race 1 strains of Ralstonia solanacearum in wild tomato germplasm. Eur. J. Plant Pathol. 122:471-479.

40. Vanitha, S. C., Niranjana, S. R., Mortensen, C. N., and Umesha, S. 2009. Bacterial wilt of tomato in Karnataka and its management by Pseudomonas fluorescens. BioControl 54:685-695.

41. Vasse, J., Frey, P., and Trigalet, A. 1995. Microscopic studies of intercellular infection and protxylem invasion of tomato roots by Pseudomonas solanacearum. Mol. Plant-Microbe Interact. 8:241-251.

42. Venables, W. N., and Ripley, B. D. 2002. Modern Applied Statistics with S. Fourth Edition. Spinger, New York.

43. Wicker, E., Coranson-Beaudu, R., Cadasse, S., and William, M. A. 2009. Emerging strains of Ralstonia solanacearum in the French West Indies raise new challenges to tomato breeders. Acta Hort. 808:279-286.

44. Wicker, E., Grassart, L., Coranson-Beaudu, R., Mian, D., and Prior, P. 2009. Epidemiological evidence for the emergence of a new pathogenic variant of Ralstonia solanacearum in Martinique (French West Indies). Plant Pathol. 58:853-861.

45. Wicker, E., Grassart, L., Coranson-Beaudu, R., Mian, D., Guilbaud, C., Fegan, M., and Prior, P. 2007. Ralstonia solanacearum strains from Martinique (French west indies) exhibiting a new pathogenic potential. Appl. Environ. Microbiol. 73(21):6790-6801.

46. Wicker, E., Lefeuvre, P., de Cambiaire, J. C., Lemaire, C., Poussier, S., and Prior, P. 2012. Contrasting recombination patterns and demographic histories of the plant pathogen Ralstonia solanacearum inferred from MLSA. The ISME Journal online publication doi:10.1038/ ismej.2011.160.

47. Yabuuchi, E., Kosako, Y., Yano, I., Hotta, H., and Nishiuchi, Y. 1995. Transfer of two Burkholderia and an alcaligenes species to Ralstonia Gen. Nov.: Proposal for Ralstonia pickettii, Ralstonia solanacearum and Ralstonia eutropha. Microbiol. Immunol. 39:897-904. 